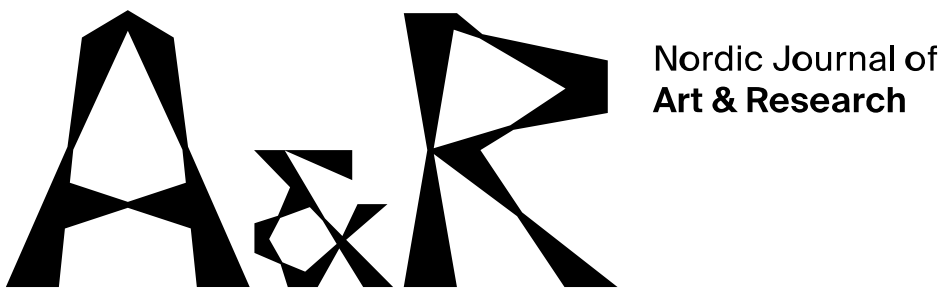

\title{
Public art as research in the open
}

\section{Thoughts on Alfredo Jaar's Studies on Happiness as situational knowledge production}

\author{
Marion Hohlfeldt ${ }^{1}$ \\ Rennes 2 University, France
}

\begin{abstract}
In 1979, the Chilean artist Alfredo Jaar staged his first public intervention in the context of military dictatorship. His inquiry on states of happiness anticipated a working method that Jaar has been following since. In taking Studies on Happiness as an early example of social aesthetics, this article will show that the work itself is not only seen as the product of making (poïesis), but that the process itself is seen as the embodiment of knowledge, the dwelling and outcome of an intended action. However, this action is not simply an act in the everyday (praxis), but as an intended action it is intelligent in itself and calls for the practical wisdom of acting (phronesis). As soon as the project includes a relational process and forms of participation, both in nature of unforeseeable outcome, the aim is no longer the production of a (common) object; rather, it is the social relation itself, established through the aesthetic or "boundary" object that puts into action the relation as well as the reflection on the conditions of its becoming. We will assess how play and phronesis can mediate between research and art by creating a situational knowledge, that is both critique and contributory: a research in the open.
\end{abstract}

Keywords: Social aesthetics, resistance, Alfredo Jaar, research in the open, potential space, situational knowledge

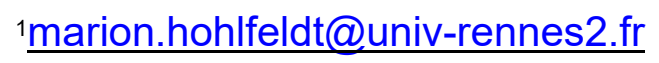




\section{Introduction}

In 1979, the Chilean artist Alfredo Jaar addressed a question to passers-by throughout the city of Santiago: "Are you happy?" In a seemingly innocent manner, he managed to disrupt daily routine and measured people's misery in a country ruled by military dictatorship. By gambling on the thin edge of authoritarian indifference facing his artistic performance, and persuaded that he could communicate with his compatriots through a staged device, Alfredo Jaar used this project as a metaphor as well as an instrument to measure situational knowledge on the political situation and to produce an awareness of the possibilities to still act on it. By holding up a mirror to the voluntary participants, Studies on Happiness inaugurated a working method that the Chilean artist has followed since. At the same time, the work represents an investigation that sheds an interesting light on methods of artistic research and asks how artists can base their critical activity on social aesthetics, while taking into account methodologies recently developed in social sciences.

During the last few decades, artistic research has gained significant ground in most Western Countries ${ }^{2}$. While research in and through the arts responds to an increasing demand by national and international organs ${ }^{3}$, artistic research still evokes a number of interrogations, which 2009 ELIA President Chris Wainwright summed up in the simple question: "what can research do for art?" The lack of common epistemology not only testifies the difficulties to reconcile ideological as well as national approaches, but also shows the interest of the value of art itself "as a complex site of critical activity that is improved by the process of research" (Wainwright, 2009, p. 105)". Research, defined as a systematic activity that is undertaken in order to increase knowledge, calls for research methods and scientific

\footnotetext{
2 The fact that artistic research is increasingly gaining discursive importance is documented by a continuously growing number of publications and networks, amongst them the Journal for Artistic Research, launched in 2011, and the European Artistic Research Network EARN, started in 2008 and since 2016 maintained by resources provided by the Academy of Fine Arts Vienna. For further publications see: Henk Borgdorff, The Conflict of the Faculties: Perspectives on Artistic Research and Academia, Leiden: Leiden University Press, 2012, and the recent Manifesto of Artistic Research: $A$ Defense Against Its Advocates (= Manifest der künstlerischen Forschung: eine Verteidigung gegen ihre Verfechter), Zurich: Diaphanes, 2020.

3 See: Peer Power! The Future of Higher Arts Education in Europe, artesnet Europe - The Erasmus Network for the Higher Arts Education sector in Europe, ed. National Academy for Theatre and Film Arts, Sophia/ ELIA European League of Institutes of the Arts, 2009, http://www.eq-arts.org/wpcontent/uploads/2016/09/Peer-Power-ArtesNetBook-.pdf.
} 
expertise that can be evaluated by peers. However, how does art practice produce knowledge? In what ways is this knowledge production different from social and human sciences, and how can this new achievement be communicated through the artwork itself? In taking Studies on Happiness as an early example of social aesthetics, this article will show that the work itself is not only seen as the product of making (poïesis), but that the process itself is seen as the embodiment of knowledge, the dwelling and outcome of an intended action. However, this action is not simply an act in the everyday (praxis), but as an intended action it is intelligent in itself and calls for the practical wisdom of acting (phronesis). As soon as the project includes a relational process and forms of participation, both in nature of unforeseeable outcome, the aim is no longer the production of a (common) object; rather, it is the social relation itself, established through the aesthetic or "boundary" object (Borgdorff, 2012, pp. 128-138) that puts into action the relation as well as the reflection on the conditions of its becoming. We will assess how play and phronesis can mediate between research and art by creating a situational knowledge, that is both critique and contributory: a research in the open.

\section{An Aesthetic of Resistance}

Do you remember September 11th? It was a Tuesday. Alfredo Jaar was seventeen when the coup d'état against the democratically elected socialist government of Salvador Allende took place on September 11th, 1973. He had just returned with his family to Chile a year before, leaving the French Caribbean island Martinique where he had lived since the age of five. His first artistic gesture was actually a date that fixed the precise moment of the first bombing: 11.09.73.12.10. And the calendar painting September 11 recalled this date like a mantra that endlessly repeated the one and always same number: 8, 9, 10,11,11,11, 11 - "an eleven for ever ever ever" as we can read on the sketch for the work -, as if there was no longer any time, as if, after September 11th, every day has become an eleven. However, and in despite of this early work, Alfredo Jaar did not choose the Faculty of Arts, but enrolled in architecture studies at the Universidad de Chile, and filmmaking at the Instituto Chileno Norteamericano, nourishing his artistic approaches by a thorough analysis of the contexts from which his objects emerge and to which they return. Studies on Happiness, realized between 1979 and 1981, is the first example of his "strategies of reversal" (Princenthal, 2005, p. 13), as he started a contextual work that gradually became "a weapon of subtle resistance" (Lippard, 2012, p. 56). Here, context defined content by shifting the frame of perception, in terms of production as well as reception, towards new conditions for life experience. 
Estudios sobre la felicidad (Studies on Happiness) was an improvised collection of public surveys, video interviews, textual fragments, photographs, and billboard public interventions. A project composed by seven stages "in a demented situation in which the artist felt both faceless and powerless" (Valdés, 2012, p. 184), the main inquiry asking people - in a reference to Hans Haacke's 1970 Poll - to vote yes or no to the following question: "Are you happy?". This apparently innocent question blurred the civic attitudes of self-control and censorship in a political atmosphere of fear and suspicion. Happiness, in the social life of Chile in those days, was, indeed, comedy, as underlined the Chilean critic Adriana Valdés: "The question of happiness surfaces in daily lies; in advice from women's magazines, in advertising; in the fabrication of 'the tyranny of the offered object', which consciously manipulates the unconscious mechanisms of desire" (Valdés, 1999, p. 63). The project made it possible for the artist to perceive himself through the eyes of others and thus to transfer the selfprojection to a context. The results of the vote were presented on notice boards that were the basis for public discussions and interviews. In a country where people were not allowed to vote, this public involvement showed ways of participation that not only were considered as a form of resistance, but also as a way to create the desire for change. Jaar later used these texts, photos and video interviews for his public presentations, which were consistently accompanied by discussions about happiness. He put up billboards with this emphatic question: "Are you happy?". Jaar also filmed the citizens of Santiago and showed their interviews in public. "I gambled on two things", he later recalled. "The first gamble was that I could accurately judge the limit of what I could do, because I meant to walk right up to that limit. The second gamble I took was that other people in Chile would understand that I was acting in a very veiled way. I gambled that other people would understand my performance" (Jaar, in Valdés, 1999, p. 63). Obviously, the artist took a risk as people were not allowed to gather in the street and as any political statement could be immediately sanctioned ${ }^{4}$.

His stratagem consisted in using an estrangement effect that immediately differentiated his public performance from any political statement. By endorsing the role of a clown who, in apparent naivety, employed smiling faces, stencilled rainbows and carved out a bizarre figure that eventually puzzled or even amused people, he

\footnotetext{
${ }^{4}$ Characterized by the systematic suppression of political parties and the persecutions of dissidents, the military dictatorship left over 3.000 dead or missing, tortured several ten thousand of prisoners and drove about 200,000 Chileans into exile.
} 
created a potential space for creative interaction. This term, coined by Donald W. Winnicott (1991) in his seminal text on play, is based on a paradoxical logic of both real and imaginary space, that is simultaneously framed and open in order to allow "states of un-integration and formlessness", in which identity can be suspended in creative play, in the "absorbed exploration of potential" (Winnicott, 1991, pp. 53-64). As a place "where we are when we are experiencing life" (p. 104), for Winnicott, potential space is the space of creative living in which new possibilities can be safely tried out because the situation can be interrupted at any time. It becomes a space that mediates between the individual and society as a kind of third type of reality and negotiates new rules up to its own reversal (Hohlfeldt, 2016, pp. 127-142). Alfredo Jaar addressed the public as a player, gambling on the mutual understanding by means of boundary objects that were presented to collect testimonies: a poll, photoportraits, posters and billboards, public events. In addressing a seemingly foolish question at times when thousands of opposing figures disappeared, and asking questions became dangerous, he made the limit visible and through this limit, the people themselves, as he underlined: "They could see themselves. They could see others. They felt complicity, and I could feel it in the way they congratulated me. They all knew to speak between the lines" (Jaar, in Valdés, p. 63). To play the game. The Chilean art critic Adriana Valdés recalls: "[...] the apparent naiveté of the questions asked [...] served in difficult times as a shield that permitted several public actions [...] and even voting on the street. For the people participating, it also involved exposing oneself and seeing oneself on-screen, something that still awed and fascinated most Chileans back in 1981." (Valdés, 2012, p. 187-188)

Jaar's performance was perceived as a laboratory situation in which he could collect information and share feelings and opinions on daily life in Santiago in 1979 to 1981. Here, the work of art is not an object anymore - unless we take it as a whole process over three years and as boundary object that made exchange possible -, it is reconceived as a long-term project $t^{5}$. By making art unrecognisable as art through its

\footnotetext{
${ }^{5}$ We follow here Claire Bishop's observation on socially engaged art in which "the artist is conceived less as an individual producer of [...] objects than as a [...] producer of situations; the work of art [...] is reconceived as an ongoing or long-tem project [...] while the audience [...] is now repositioned as a co-producer or a participant". See: Claire Bishop, Artificial Hells. Participatory art and the Politics of Spectatorship, London/ New York, Verso, 2012, p. 2.
} 
"de-artification" [Entkunstung] - to use Adorno's term ${ }^{6}$-, the long-term process allows the project to develop its subversive potential in daily life: it illuminates contexts, raises questions beyond one's own horizon and, eventually, produces a change through genuine experience.

In his text on social aesthetics, the Danish critic Lars Bang Larsen (2006) underlines the processual character of the ways these projects can forge connections between aesthetic knowledge and the surrounding society. Social aesthetics' concept of reality is based on dialogue with people in and on concrete situations in a perspective of democratic and social processes, negotiating the meaning of aesthetics in relation to the desire to expand forms of democratic action: "The social aesthetic involves a utilitarian or practical aspect that gives a sense of purpose and direct involvement [...]", "an artistic attitude focusing the world of acts" (Larsen, 2006, p. 172-183). This "artistic attitude" seems to be a key notion for the understanding of artistic research, as it expresses experimental approaches to practice that bring up new questions and call for new methodologies, which are not reserved to artists and which need not to produce a work of art; instead, they introduce new points of view and open new perspectives to emerge in a process of "unfinished thinking" (Borgdorff, p. 212). Experimental practices occur like accidents as they are both structurally open and linked to the changing territory that they perform. Yet, turning a spotlight onto a given situation through creative exploration opens up a potential space between and betwixt the real and the imaginary in which serious items can be enacted. In her book on participatory art, Claire Bishop (2012, p. 284) stresses: "In using people as a medium, participatory art has always had a double ontological status: it is both an event in the world, and at one removed from it. As such, it has the capacity to communicate [...] the paradoxes that are repressed in everyday discourse, and [...] enlarge our capacity to imagine the world and our relations anew." Emphasizing collaborative practices that take the form of a laboratory model, social aesthetics are at once clearly defined without, and receptive for action within, a pre-determined, and yet open, artistic device: research in the open.

${ }^{6}$ Entkunstung has often been translated by "de-aestheticization", although "de-artification" seems to better fit the sense of the destruction of art's quality as art. See: Theodor W. Adorno, Aesthetic Theory, London, Continuum, 2004, p. 22. 


\section{Research in the open}

Socially engaged art is largely based on long-term projects, which the audience can co-produce or in which it can participate to a certain extent. While working by project is a common characteristic for a certain number of fields, i.e. architecture, engineering, design; it has been introduced into the vocabulary of art making at the end of the 1980s, when "context" "process", "project" and "practice" turned into common terminology. The process(es) of production became more interesting than the product; forms of action more significant than modes of expression (Rollig, 1998, pp. 12-27). Nowadays, most research funding is attributed by project, which makes the project a research tool in its own right, capable of accumulating and valueing knowledge in a defined period of time, and in favour of concrete application by civil society. Yet, as a figure, the project has become the organisational matrix of many human activities in postmodern societies, expressing, according to Jean-Pierre Boutinet (1990), the relation societies have with time, as the project seeks to anticipate the future. The term project indeed refers to what is intended to be done, and normally specifies the means that seem to be necessary to implement the idea. Derived from the Latin projectum "before an action", it covers nevertheless in most European languages a double meaning as it signifies the intention as well as the action. It is therefore often described as a dynamic system that develops along plan, process, people and power towards a realisation of the initial idea. We then understand that theory and practice, individual and collective, time and space, success and failure, constitute the essential elements of this continuous and dynamic tension from which the project itself emerges. And Alain Findeli (2007), who coined the term of Project-grounded research ("recherche-projet" in French), specified: "It is an 'active' type of research, located and engaged in the field of a project (therefore its translation project-grounded research), the project being the equivalent for us of the 'field' of social sciences and the 'laboratory' of experimental research. We would like to point out that to think well or correctly ["penser juste" in French] in design [or in art], you have to think 'in action' [...]" (Findeli, 2015, p. 55).

In Studies on Happiness, Alfredo Jaar, who actually calls himself a "project artist" (Mouffe, 2012, p. 273), used the project as a metaphor and as an instrument for his research in the open. By experimenting with media, sociological tools, advertising and playful diversion, he produced a shift in the perception of the political context from which the work arose. By means of "performative folding" (Levan, 2011, p. 84), he created a situation that was not only addressed but also interactive, a real temporal and spatial parenthesis that not only produced critical thinking in act, but also disturbed "casual looking by demanding to be seen" (Lippard, p. 53). This 
negotiation with reality questioned the ability of art to rethink its modalities of use and its forms of resistance through a direct contact with the street and confirmed, to some extent, a statement by James Baldwin: "Life is more important than art, that's what makes art important"7. This question has been treated from a different point of view by the sociologist Pascal Nicolas-Le Strat (2018), who proposes a new configuration for a critical sociology. For him, "A critical sociology strives, in concrete terms, to reintroduce the process, to make shifts, to identify new horizons of meaning and action, because a reality is never as accessible to analysis and criticism as when it is transformed, uncovered and found in imbalance. Reorganizing or creating a situation; evaluating the scope of the dynamics that are beginning and the relationships that are being established in this new context; thinking and acting these transformations in a critical confrontation, as quickly as they are implemented: these three moments are inseparable, each becoming the presupposition of the other, the better analyst of the other" (Nicolas-le Strat, 2018, p. 12).

This sociology in situation overcomes the separation between observation and hypothesis, as it is project-grounded, both critique and contributory to the real, which Nicolas-Le Strat calls in the open [de plein vent]. Thus, research turns into actionresearch that opens a real temporal and spatial parenthesis, a kind of interstice that is ontologically related to the potential space defined earlier. This research in experimental situation also raises the tricky question of an art in the making which will not necessarily produce a work, but which works to produce knowledge through experimentation, as common ground. Research in experimental situations as common ground, benefits from the plurality of knowledge, as the project is open: a hypothesis at work, elaborating as the project evolves. Yet, this experimental, projectgrounded action-research, necessarily modifies scientific hierarchies, starting by redefining expertise, by privileging a more horizontal approach that includes expertise from civil society and practical knowledge (farmers, workers, users, educators, etc. $)^{8}$.

\footnotetext{
7 This quote, taken from the book The Fire New Time, New York: The Dial Press, figures also on the first page of the Alfredo Jaar catalogue on his public interventions, see: Nancy Princenthal, Alfredo Jaar. The Fire This Time: Public Intervention 1979-2005, Milan, Charta, 2005.

${ }^{8}$ As already Michel de Certeau explained, it "would be legitimate to define the power of knowledge by this ability to transform the uncertainties of history into readable spaces. But it would be more correct to recognize in these "strategies" a specific type of knowledge, one sustained and determined by the power to provide oneself with one's own place. [...] In other words, a certain power is the precondition of this knowledge ...". See: Michel de Certeau, The Practice of Everyday Life, trans. by Steven
} 
This specific type of knowledge does not ground power on social status or a specific scientific apparatus. Experimental research takes the risk of incompetence, in bridging over to new fields of knowledge and valuing new points of view. The inevitable uncertainty not only obliges us to look more closely, but it also equalizes the social hierarchy, as everyone in experimental situations is novice. For socially engaged, public art, this embedded action grounds the artwork on the (shared) processes itself as the embodiment of knowledge. The dwelling and outcome of this intended action, yet is not simply an act in the everyday, but it produces insight and practical wisdom.

\section{Situational knowledge}

We can say that social aesthetics necessarily create within fields of research that bridges over from aesthetics towards human and social sciences. It may adapt its methodologies: inquiries, observation, experimentation, and field studies; the main achievement, however, lays in its production of a signification shift. This essay asked, how does art practice produce knowledge? As demonstrated, Studies on Happiness is not just the product of a process of making (poïesis); it is the very process itself that produces insight and knowledge, and "makes". It is not only an act in the everyday (praxis), it also produces a signification shift that "makes" a difference. As practice-based research, it creates a bridge between scientific knowledge (episteme) and technical knowledge (techne) to become a third type of knowledge that we may call, in reference to Aristotle: phronesis. Phronesis concerns the practical judgment of which virtues and values are at stake in a given context in order to evaluate ethical decisions (Aristotle, 2009). It is not just general knowledge of the good in itself, but it is rather "concerned with the human existential goal to obtain knowledge or insight of the happy or flourishing life (eudaimonia)." (Duvenage, 2015, p. 78). As such, phronesis cannot be achieved through a master plan or blueprint that would be applied to daily life. Its goals are not previously fixed, but instead evolve; they are cocreated through multi-voiced and heterogenous commitments towards context by diverse social and aesthetic interactions. Phronesis is formed from - and forms - the sensus communis (Gadamer, 2004, p. 17-27), the good co-existence, the political and social engagement. While the art object maintains an obvious link to skifful

Rendall, Berkeley/ Los Angeles/ London, University of California Press, 1984, p. 36 (“Making do": Uses and Tactics). 
Marion Hohlfeldt. Public art as research in the open

making, ephemeral practices and socially engaged interventions shift the attention to this practical wisdom on the common (sense).

In borrowing from Gadamer's seminal book Truth and Method (2004), we state that phronesis, in echo of the ontological being of play as a kind of "third type of reality", is able to mediate between episteme and techne by creating a situational knowledge, that is both critique and contributory, as Nicolas-Le Strat put it: a research in the open (Nicolas-Le Strat, 2018, p. 12) Play and phronesis ground a concept of understanding that takes our involvement and partiality not as a barrier to understanding, but rather as its enabling condition. They can be seen as key figures in the specific ways not only Studies on Happiness worked, but also as a central framework for social aesthetics on a larger scale. However, we like to follow Adriana Valdés when she expresses her unease at trying to explain what this work is actually about: "Studies on Happiness is not "about" happiness at all; I wonder if it is "about" anything. If I had to say what it is "about", I would say it was "about" Chilean people during those years; or "about" art and its possible dimensions as a social experiment; or even, "about" the artist's thinking, which was in itself in process, being developed and created within the structure he devised for the work." (Valdés, 2012, p. 188). The fact is, the work itself remained an unfinished process in which the participatory installation of exchange and dialogue produced hundreds of hours of videotapes, that were never transformed into a clearly defined work or as such disseminated; they stayed at the stage of a project that was put up a as a test situation in order to evaluate the limits - and possibilities - of public space in Chile at that time, of which the reception was uncertain (Peláez, 2019). The prize awarded to him, however, precipitated his departure to New York City where he has been working ever since. While it is impossible to say whether Studies on Happiness triggered phronesis as the award may suggest, it certainly stressed the protection and attunement of play and its potential space to make dialogue and insight possible.

\section{Conclusion}

Artistic research on public space is inevitably embedded, contradictory, and plural. Taking into account some aspects of participating observation and action-research, these experiences often lead to a heterogeneous material of notes, taken on the terrain, records and reports, photographs, sketches, sound tapes, and other texts already put into narratives. While artistic research can be understood as a toolbox that allows us to think from context about forms of action that constantly modify the toolbox itself, it still does not necessarily produce an object of art. Alfredo Jaar's collection of material throughout his three-year-long process of Studies on Happiness 
still remain unused, waiting as tremendous potential in the artist's archive. "In retrospect, the material gathered for the project, including many hours of Chileans on tape answering questions about their own happiness in 1981, is deeply disturbing, not only because of what it says but also because of the glaring omission in what people say and do" (Valdés, 2012, p. 186), underlines Adriana Valdés. While artistic research in the open may focus on the phronesis of the project and produce tools and laboratory situations rather than objects, the collected material as knowledge, as archive is still valuable and, in some cases - the situation in Chile under Pinochet or in Rwanda during the genocide -, even highly explosive as they may contradict official memory. Artistic research in the open may not necessarily be about something, but as a project, as a process, it still produces insight at least about the art itself; its possible dimension as a social experiment and its disruptive powers to impeach the established in order to produce new ways of seeing.

\section{About the author}

Marion Hohlfeldt is assistant professor in Contemporary Art History at the Institute for Visual Arts, at Rennes 2 University, France, and co-director of the research program "Art and Politics". She has been working on art and public space, as research assistant at the Centre Georges Pompidou, and in collaboration with Jochen Gerz. Editor of several books, she published Faire la Cité. Création et gouvernement des imaginaires urbains, Bruxelles, La Lettre volée, 2016. Since 2020, she is director of the international and interdisciplinary Graduate School for Creative Approaches to Public Space. https://perso.univ-rennes2.fr/marion.hohlfeldt

\section{References}

Adorno, T. W. (2004), Aesthetic Theory. London: Continuum, 2004.

Alfredo Jaar. The way it is. An Aesthetics of Resistance, with texts by Frank Wagner, Lucy R. Lippard, Adriana Valdés, Steffen Haug, Chantal Mouffe, Christian Höller, and Michaela Richter, Welcome by Klaus Wowereit, Foreword by Karin Rebbert. Berlin: RealismusStudio/ Neue Gesellschaft für Bildende Kunst, 2012.

Aristotle (2009), Nichomachean Ethics, transl. by R.C. Bartlett and S.D. Collins. Chicago: Chicago University Press, 2009.

Artistic Research, eds. A. W. Balkema and H. Slager. Amsterdam: Rodopi, 2004. Bishop, C. (2012), Artificial Hells. Participatory art and the Politics of Spectatorship.

London/ New York: Verso, 2012. 
Marion Hohlfeldt. Public art as research in the open

Borgdorff, H. (2015), "Artistic Research: Unfinished Thinking in and through Art”, in Stefan Horn, Valentina Rojas Loa, Caroline Wanjiku Kihato, Terry Kurgan (eds), Nine Urban Biotopes. Negotiating the Future of Urban Living, Nine Urban Dialogues, www.urban-biotopes.net.

Borgdorff, H. (2012), The Conflict of the Faculties: Perspectives on Artistic Research and Academia, Leiden: Leiden University Press, 2012.

https://doi.org/10.26530/OAPEN 595042

Boutinet, J-P. (1990), Anthropologie du projet, Paris: PUF, 1990.

Duvenage, P. (2015), "Pratical wisdom (phronesis) and hermeneutical politics", in Phronimon, vol. 16, n¹, 2015, p. 77-96, https://doi.org/10.25159/24133086/3813.

Henke, S., Mersch, D., van der Meulen, N., Strässle, T. and Wiesel, J. (2020), Manifesto of Artistic Research. A defense against its advocates, Zurich: Diaphanes, 2020. https://doi.org/10.4472/9783035802665

Findeli, A. (2015), "La recherche-projet en design et la question de la question de recherché : essai de clarification conceptuelle”, in Science du Design, $\mathrm{n}^{\circ} 1$, 2015, pp. 45-57. https://doi.org/10.3917/sdd.001.0045

Gadamer, H-G. (2004), Truth and Method [1960], transl. by J. Weinsheimer and D. G. Marshall, New York: Continuum, 2004.

Hohlfeldt, M. (2016), "À la Recherche d'un Nouveau Spectateur: The Function and Significance of Play in the Participatory Environments of the Groupe de Recherche d'Art Visuel", in Practicable. From Participation to Interaction in Contemporary Art, eds. Samuel Bianchini and Eric Verhagen, Cambridge, MA/ London: The MIT Press, 2016, pp. 127-142.

Huyghe, P.-D. (2017), Contre-temps. De la recherche et de ses enjeux. Arts, architecture, design, Paris: ed. B 42, 2017.

Jaar, A., Valdés, A. (1999), Estudios sobre le felicidad, 1979-1981. Barcelona: ACTAR, 1999.

Larsen, L. B. (2006), "Social Aesthetics, 1999”, in Participation, ed. Claire Bishop, London: Whitechapel, 2006, pp. 172-183.

Levan, M. (2011), "Folding Trauma: On Alfredo Jaar's installations and interventions", in Performance Research, vol. 16, $\mathrm{n}^{\circ} 1,2011$, pp. 80-90.

https://doi.org/10.1080/13528165.2011.561678

Lippard, L.R. (2012), "What World Are You Living In”, in Alfredo Jaar. The way it is. An Aesthetics of Resistance, Berlin: RealismusStudio/ Neue Gesellschaft für Bildende Kunst, 2012, pp. 48-98. 
Marion Hohlfeldt. Public art as research in the open

Mouffe, C. (2012), "Alfredo Jaar: The Artist as Organic Intellectual", in Alfredo Jaar. The way it is. An Aesthetics of Resistance, Berlin: RealismusStudio/ Neue Gesellschaft für Bildende Kunst, 2012, pp. 264-282.

Nicolas-Le Strat, P. (2018), Quand la sociologie entre dans l'action, Rennes: Ed. du commun, 2018.

Peláez, S. (2019), "Studios sobre la Felicidad: Alfredo Jaar y el estremecimiento del goce ", in Aisthesis, no. 65, 2019, https://doi.org/10.7764/aisth.65.2

Princenthal, N. (2005), Alfredo Jaar. The Fire This Time: Public Intervention 19792005, Milan: Charta, 2005.

Valdés, A. (2012), "Missing Chile: Far South. Far. Very Far", in Alfredo Jaar. The way it is. An Aesthetics of Resistance, Berlin: RealismusStudio/ Neue Gesellschaft für Bildende Kunst, 2012, pp. 180-203.

Winnicott, D. W. (1991), Playing and Reality [1973], London: Routledge, 1991. 